\title{
Mungbean yield and nutrient uptake performance in response of NPK and lime levels under acid soil in Vindhyan region, India
}

\author{
Ram Swaroop Meena* and Dinesh Varma \\ Department of Agronomy, Institute of Agricultural Sciences, BHU, Varanasi (UP-221 005), INDIA \\ ${ }^{*}$ Corresponding author. E-mail: meenars@bhu.ac.in \\ Received: October 9, 2015; Revised received: February 23, 2016; Accepted: May 24, 2016
}

\begin{abstract}
A field experiment was conducted to understanding the management of soil acidity with NPK and lime levels for sustainable mungbean productivity, Crop was sown during kharif season of 2014at Agronomy farm of Rajiv Gandhi South Campus Banaras Hindu University, Barkachha, Mirzapur, Uttar Pradesh. Results of the study demonstrated that significant improvement in seed (524 kg /ha), straw (1426 kg /ha), biological yield (1949 kg/ha) and total NPK uptake $(96.68 \mathrm{~kg} / \mathrm{ha})$ were recorded in $100 \%$ RDF. Similar results were observed with application of $200 \mathrm{~kg}$ lime/ha in mungbean. Interaction effect was also recorded at $P=0.05$ level of significance between fertility and lime levels on mungbean seed $(622 \mathrm{~kg} / \mathrm{ha})$ and biological $(2145 \mathrm{~kg} / \mathrm{ha})$ yield with $100 \%$ RDF $+200 \mathrm{~kg}$ lime/ha which were observed highest than all other treatments. Moreover, highest B:C ratio was observed with the application of $200 \mathrm{~kg}$ lime/ha. The present study revealed that soil acidity problems affecting pulses productivity, can be overcome with applications of $100 \%$ RDF and $200 \mathrm{~kg}$ lime/ha in Vindhyan region, India.
\end{abstract}

Keywords: Acid soil, Fertility Levels, Lime, Mungbean, Yield

\section{INTRODUCTION}

India grows nearly 24 million ha of pulses with the annual production of 18.50 million tonnes and productivity is $730 \mathrm{~kg} / \mathrm{ha}$, whereas USA and Canada's productivity is as high as $1900 \mathrm{Kg} /$ hectare.(GOI, 2015). Mungbean [Vigna radiate (L.) Wilczek] is widely used in India and is consumed as dehusked green gram split (dhal) in the form of cooked dhal and deep fat fried snack item. The composition of mungbean split (per $100 \mathrm{~g}$ ) is as follows: protein $21-24 \mathrm{~g}$, fat $1.31 \mathrm{~g}$, minerals $3.48 \mathrm{~g}$, fiber $4.11 \mathrm{~g}$, carbohydrates $56.72 \mathrm{~g}$, energy $334 \mathrm{kcal}$, calcium $124 \mathrm{mg}$, phosphorous $326 \mathrm{mg}$ and iron $4.42 \mathrm{mg}$ (Gopalan et al., 2002; Dhakal et al., 2015). Acid soils make up approximately $30 \%$ of the world's total land area and more than $50 \%$ of the world's potentially arable lands, particularly in the tropics and subtropics (Kochian et al., 2004; Meena and Yadav, 2014). Soil acidity is a major factor affects root growth and nutrient availability to the plants. Acidic soils cause's significant losses in mungbean production and where the choice of crops is restricted to acid tolerant species and varieties, profitable market opportunities may be reduced. The associated chemical changes in the soil can restrict the availability of essential plant nutrients specially; macro nutrients are i.e. nitrogen, phosphorus and potassium. Essential plant nutrients can also be leached below the rooting zone in acid soil. Biological processes favorable to plant growth may be affected adversely by acidity (Lambridge and Godwin, 2007). Soil acidity have a major impact on mungbean productivity for sustainable farming systems, and acidification can also extend into subsoil layers posing serious problems for plant root development and remedial action.Application of finely crushed limestone, and other liming material, is the only practical way to neutralize the soil acidity (Alleoni et al., 2010). The most commonly used liming material is agricultural limestone, the most economical and relatively easy to manage source. The limestone is not very water-soluble, making it easy to handle. Hence, the present field study was carried out to find out appropriate soil acidity management with lime to increase mungbean productivity with NPK application in acid soil of vindhyan region, India.

\section{MATERIALS AND METHODS}

A field experiment was conducted during kharif season of 2014-15 at Agronomy farm of Rajiv Gandhi South Campus Banaras Hindu University, Barkachha, Mirzapur, Uttar Pradesh (Fig. 1). This is situated in Vindhyan region of district Mirzapur $\left(25^{\circ} 10^{\prime}\right.$ latitude, $82^{0} 37^{\prime}$ longitude and altitude of 89 meters above mean sea level. This region comes under agro-climatic zone III A (Semi-Arid Eastern Plain Zone) and the region is mostly rainfed. Crop was sown in agro-horti based system between rows of custard appletree spacing of 7 X 7 meter, custard appletrees were 8 year old planted in august 2008. The soil of the experimental site was sandy loam and having $186 \mathrm{~kg} / \mathrm{ha}$ alkaline permanganate oxidizable N (Subbiah and Asija, 1956), 
$20.98 \mathrm{~kg} / \mathrm{ha}$ available P (Olsen et al., 1954). Available $\mathrm{K} 243.48 \mathrm{~kg} / \mathrm{ha}$ analyze with flame photometer method (Stanford and English, 1949) and 0.37\% organic carbon (Walkely and Black, 1947). The $\mathrm{pH}$ of soil was 5.81 analyzed with glass electrode $\mathrm{pH}$ meter (Jackson, 1973). The experiment was laid out in factorial randomize block design with three replications assigning 16 treatments combinations consisting four levels of fertility@ Recommended dose of fertilizers i.e. (Control, 75\% RDF, 100\% RDF, 125\% RDF) and lime (Control, $100 \mathrm{~kg} / \mathrm{ha}, 200 \mathrm{~kg} / \mathrm{ha}, 300 \mathrm{~kg} / \mathrm{ha}$ ). RDF was $20: 40: 20 \mathrm{~kg} / \mathrm{ha}\left(\mathrm{N}_{2}: \mathrm{P}_{2} \mathrm{O}_{5}: \mathrm{K}_{2} \mathrm{O}\right)$. Mungbean variety HUM 12 was sown at a spacing of $30 \mathrm{~cm} \times 10 \mathrm{~cm}$ on 15 August in 2013. Application of RDF (Recommended dose of fertilizers) were applied as per treatment through Urea, DAP and MOP basally in the furrows just before sowing at depth of $8-10 \mathrm{~cm}$. Lime was used for surface application before sowing at a depth of $15 \mathrm{~cm}$. All the data obtained were statistically analyzed using the F-test (Gomez and Gomez, 1984). Critical difference $(\mathrm{CD})$ values at $P=0.05$ were used for determine the significance of differences between mean values of treatments.

\section{RESULTS AND DISCUSSION}

Crop and weather: The climate of experimental Agricultural Research Farm is typically semi-arid to subhumid, characterized by extremes of temperature both in summer and winter with low rainfall and moderate humidity. Maximum temperature in summer is as high as $45^{\circ} \mathrm{C}$ and minimum temperature in winter falls below $10^{\circ} \mathrm{C}$. The rainfall was received $564.14 \mathrm{~mm}$ during the experiment conducted on mungbean,out of the total rainfall more than 56.57 per cent received between 34 to 35 Standard Meteorological Weeks (SMW). Maximum and minimum temperature fluctuated between $35.95^{\circ} \mathrm{C}$ and $24.16^{\circ} \mathrm{C}$ and relative humidity between 97.47 and 91.11 are presented in Fig.1 [Source: Observatory, KrishiVigyan Kendra, R.G.S.C, BHU, Mirzapur (UP), India].

Effect of fertility levels: Results were concluded that to understanding the management of fertility levels on mungbean.The data parented (Table1and2) show that amongst RDF of fertility levels, maximum improvement at $P=0.05$ level of significancein seed, straw, biologicalyields and NPKuptake were re-

Table 1. Effect of fertility and lime levels on yields and harvest index of mungbean.

\begin{tabular}{lllll}
\hline \multirow{2}{*}{ Treatment } & \multicolumn{3}{c}{ Yield $\mathbf{k g} / \mathbf{h a})$} & Economics \\
\cline { 2 - 4 } & Seed & Straw & Biological & Batio \\
\hline Fertility levels (\% RDF) & & & & 2.04 \\
Control & 346 & 1207 & 1554 & 2.08 \\
75 & 429 & 1.29 & 757 & 2.18 \\
100 & 524 & 1425 & 1949 & 2.08 \\
125 & 526 & 1426 & 1952 & - \\
SEm \pm & 0.03 & 0.06 & 0.08 & - \\
CD $(P=0.05)$ & 0.09 & 0.18 & 0.24 & 2.08 \\
Lime levels (kg/ha) & & & & 2.13 \\
Control & 355 & 1216 & 1572 & 2.23 \\
100 & 426 & 1327 & 1752 & 2.14 \\
200 & 520 & 1419 & 1938 & - \\
300 & 524 & 1424 & 1949 & - \\
SEm \pm & 0.03 & 0.06 & 0.08 & \\
CD $(P=0.05)$ & 0.09 & 0.18 & 0.24 & \\
\hline
\end{tabular}

$\mathrm{RDF}=$ Recommended dose of fertilizer.

Table 2. Interaction effect of fertility and lime levels on yield $(\mathrm{kg} / \mathrm{ha})$ of mungbean.

\begin{tabular}{|c|c|c|c|c|c|c|}
\hline \multicolumn{2}{|c|}{ Fertility/Lime levels (kg/ha) } & \multirow[t]{2}{*}{ Control } & \multirow[t]{2}{*}{$75 \%$ RDF } & \multirow[t]{2}{*}{$100 \%$ RDF } & \multirow[t]{2}{*}{$125 \%$ RDF } & \multirow[t]{2}{*}{ Mean } \\
\hline Seed yield & & & & & & \\
\hline Control & 297 & 363 & 373 & 387 & 355 & \\
\hline 100 & 322 & 426 & 459 & 497 & 426 & \\
\hline 200 & 393 & 466 & 622 & 597 & 520 & \\
\hline 300 & 373 & 459 & 638 & 621 & 524 & \\
\hline Mean & 346 & 429 & 524 & 526 & 456 & \\
\hline $\mathrm{CD}(P=0.05)$ & 019 & $\mathrm{SEm} \pm$ & 06 & & & \\
\hline \multicolumn{7}{|l|}{ Biological yield } \\
\hline Control & 1339 & 1626 & 1647 & 1675 & 1572 & \\
\hline 100 & 1547 & 1751 & 1817 & 1894 & 1752 & \\
\hline 200 & 1682 & 1833 & 2145 & 2094 & 1938 & \\
\hline 300 & 1647 & 1818 & 2186 & 2144 & 1949 & \\
\hline Mean & 1554 & 1757 & 1949 & 1952 & 1803 & \\
\hline $\mathrm{CD}(P=0.05)$ & 48 & $\mathrm{SEm} \pm$ & 17 & & & \\
\hline
\end{tabular}

$\mathrm{RDF}=$ Recommended dose of fertilizer. 
Table 3. Effect of fertility and lime levels on total nutrient NPK uptake by mungbean.

\begin{tabular}{lllll}
\hline \multirow{2}{*}{ Treatments } & \multicolumn{3}{c}{ Nutrient uptake (kg /ha) } & Total NPK uptake (kg /ha) \\
\cline { 2 - 3 } & Nitrogen & Phosphorus & Potassium & \\
\hline Fertility levels (\% RDF) & & & & 51.75 \\
Control & 22.20 & 3.18 & 26.37 & 71.26 \\
75 & 31.60 & 4.59 & 35.07 & 96.68 \\
100 & 43.08 & 6.35 & 47.25 & 97.04 \\
125 & 43.25 & 6.36 & 47.43 & 0.77 \\
SEm \pm & 0.47 & 0.07 & 0.38 & 2.24 \\
CD $(\mathrm{P}=0.05)$ & 1.35 & 0.19 & 1.09 & \\
Lime levels (kg/ha) & & & & 53.85 \\
Control & 23.20 & 3.34 & 27.32 & 71.43 \\
100 & 31.78 & 4.63 & 35.01 & 94.69 \\
200 & 42.12 & 6.19 & 46.38 & 96.76 \\
300 & 43.03 & 6.32 & 47.41 & 0.77 \\
SEm \pm & 0.47 & 0.07 & 0.38 & 2.24 \\
CD $(\mathrm{P}=0.05)$ & 1.35 & 0.19 & 1.09 & \\
\hline
\end{tabular}

$\mathrm{RDF}=$ Recommended dose of fertilizer.

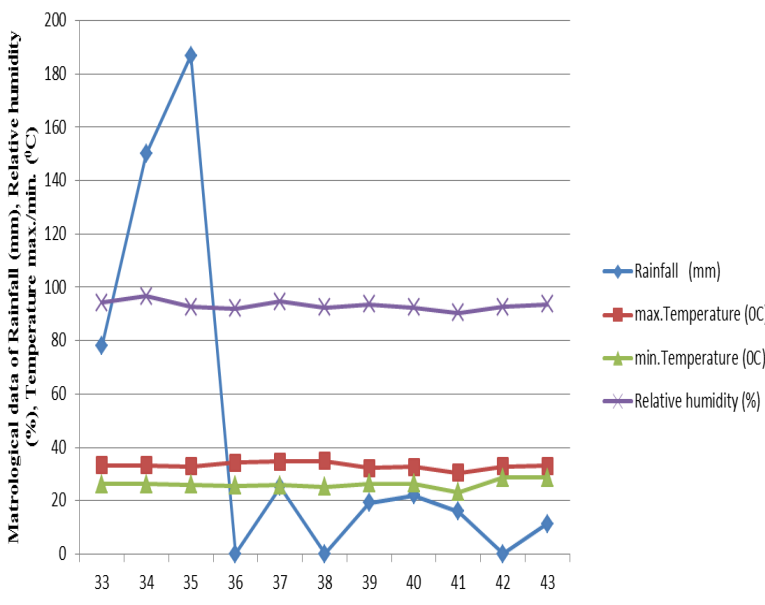

Fig. 1. Mean week-wise meteorological data during crop season kharif 2013.

corded in $100 \%$ RDF.Macro nutrientsNPK were more responsive for vegetative growth, and play important role for crop growth and development (Meena et al., 2013; Meena et al,. 2015a). Nitrogen is a component of chlorophyll and is required for several enzyme reactions for better plant growth. The right amount of phosphorus can help crops yield more pods and create healthier stocks and root systems (Meena et al., 2015b). Both nutrients are playskey role in mungbean seed formationand are responsible for keeping the system operating smoothly of mungbean plants, overall an increase in seed, straw, biological yield and nutrient contentwere mainly attributed to greater number of growth and yield parameters of mungbean. Potassium is important for a plant's ability to withstand in extreme conditions (Sheldrick et al., 2011; Meena and Yadav, 2015). In general, NPK were responsible for increased plant height, nodulation pattern, growth and yield parameters or ultimately yields and quality of mungbean. The present results are also in agreement with the findings on legume crops work has been done by several work- ers Browne et al. 2008; Awomiet al. 2012; Meena, 2013; Meenaet al., 2015b.

Effect of lime levels: Amongst lime levels, similarly results parented (Tableland2) that amongst lime levels, maximum improvement were recordedat $P=0.05$ level of significancein seed, straw, biological yields and NPK uptake in mungbean (Table 2) were recorded in lime application $200 \mathrm{~kg} / \mathrm{ha}$. Lime is usually added to acid soils to increase soil $\mathrm{pH}$. Soil acidity management with lime is increase crop production due to increase nutrient availability in soil; primarily by improve root growth due to increase NPK and other nutrients availability for plant (Brady and Weil,2002).Moreover, acidic soils are poor in their basic cautions and some micronutrients which are as essential to crop growth and productivity. This was further substantiated by several reports that application of lime on acid soils is beneficial in situation where nutrients in the soil are made unavailable due to very low $\mathrm{pH}$ or high acidity (Wang et al., 2006).

Interaction effect: Interaction effect was recorded at $P=0.05$ level of significance between fertility and lime levels on seed and biological yield of mungbean with $100 \% \mathrm{RDF}+200 \mathrm{~kg}$ lime/ha which were observed highest than all other treatments (Table 3 ). Liming is a common practice used to improve soil properties. It has both direct and indirect positive effect on soil acidity, mobilization of plant nutrients, soil aggregates and structure, biological activities of soils (Tyler and Olsson, 2001; Bolan et al., 2003; Meena et al., 2015).

\section{Conclusion}

The present study concluded that soil acidity problems are commonly affect pulses productivity, it can be overcome with applications of $100 \%$ RDF and $200 \mathrm{~kg}$ lime/ha in Vindhyan region, India. Results of the study demonstrated that significant improvement in seed (524 kg /ha), straw (1426 kg /ha), biological yield $(1949 \mathrm{~kg} / \mathrm{ha})$ and total NPK uptake $(96.68 \mathrm{~kg} / \mathrm{ha})$ were 
recorded in $100 \%$ RDF. Similar results were observed with application of $200 \mathrm{~kg}$ lime $/$ ha in mungbean. Interaction effect was also recorded at $P=0.05$ level of significance between fertility and lime levels on mungbean seed (622 kg/ha) and biological $(2145 \mathrm{~kg} / \mathrm{ha})$ yield with $100 \% \mathrm{RDF}+200 \mathrm{~kg}$ lime/ha which were observed highest than all other treatments. Soil acidity have a major impact on mungbean productivity for sustainable farming systems, and acidification can also extend into subsoil layers posing serious problems for plant root development and remedial action. On the basis of conducted field experiment recommended that limestone and other liming material, is the only practical way to neutralize the soil acidity and increase productivity of mungbean.

\section{REFERENCES}

Alleoni, L.R.F., Cambri, M.A., Caires, E.F. and Garbuio, F.J. (2010). Acidity and aluminum speciation as affected by surface liming in tropical no-till soils. Soil Science Society American Journal, 74:1010-1017.

Awomi, T.A., Singh,A.K., Kumar, M. and Bordoloi, L.J. (2012). Effect of phosphorus, molybdenum and cobalt nutrition on yield and quality of mungbean (Vigna radiate L.) in acidic soil of Northeast India. Indian Journal of HillFarmarming, 25 (2): 22-26.

Bolan N.S., Adriano D.C., Curtin D. (2003).Soil acidification and liming interactions with nutrient and heavy metal transformation and bioavailability.Advances in Agronomy, 78: 215-272.

Brady, N.C. and Weil, R.R .(2002). The nature and properties of soil $13^{\text {th }}$ edition, Prentice Hall, New Jersey.

Browne, T.T., Koenig, R.T., Huggins, D.R., Harsh, J.B. and Rossi, R.E. (2008). Lime effects on soil acidity, crop yield, and aluminum chemistry in direct seeded cropping systems. Soil Science Society American Journal, 72: 634-640.

Dhakal,Y., Meena, R.S., De, N.Verma, S.K. and Singh, A. (2015). Growth, yield and nutrient content of mungbean (Vignaradiata L.) in response to INM in eastern Uttar Pradesh, India. Bangladesh journal of Botany, 44 (3): 479-482.

GOI. (2011). Economic Survey of India, Ministry of Finance (Economic Division) GOI, New Delhi. Pp 17-22.

Gomez, K.A and Gomaz, A.A. (1984).Statistical Procedures for Agricultural Research. John Wiley and Sons, Singapore.

Gopalan, C., Rama Sastri, B.V. and BAlasubramanian, S.C. (2002).Nutritive Value of Indian Foods, National Institute of Nutrition, Hyderabad, India.pp 76-82.

Jackson, M .L. (1973).Soil Chemical Analysis.Prentice Hall of Inc. Engle Chiffs. New Jersey.
Kochian, L.V., Hoekenga, O.A. and Piners, M.A. (2004). How do crop plants tolerate acid soils: Mechanism of aluminum tolerance and phosphorus efficiency. Annual Review of Plant Biology, 55: 459-493.

Lambridge, C.J., Godwin, I.D. (2007). Mungbean. In: Kole $\mathrm{C}$, editor. Genome mapping and molecular breeding in plants, Volume 3: Pulses, sugar, and tuber crops. Heidelberg: Springer Verlag. pp. 69-90.

Meena, R.S. (2013). Response to different nutrient Sources on green gram (Vignaradiata L.) Productivity. Indian Journal of Ecology, 40(2): 353-355.

Meena, R. S. and Yadav R. S. (2014).Phenological Performance of Groundnut Varieties under Sowing Environments in Hyper Arid Zone of Rajasthan, India.Journal of Applied and Natural Science, 6 (2): 344-348.

Meena, R. S. and Yadav, R. S. (2015). Yield and Profitability of Groundnut (ArachishypogaeaL) As Influenced by Sowing Dates and Nutrient Levels With Different Varieties. Legume Research, 38 (6): 791-797.

Meena, R.S., Dhakal, Y., Bohra, J.S., Singh., S.P., Singh, M.K. and Sanodiya, P. (2015a). Influence of Bioinorganic Combinations on Yield, Quality and Economics of Mung Bean.American Journal of Experimental Agriculture, 8 (3): 159-166.

Meena, R.S., Yadav, R.S., Meena, H., Kumar, .S, Meena,Y. K. and Singh, A. (2015b). Towards the current need to enhance legume productivity and soil sustainability worldwide: A book review.Journal of Cleaner Production, 104: 513-515.

Olsen, S..R, Cole, C.V., Watanabe, F.S. and Dean, L.A. (1954). Estimation of available phosphorus in soils by extraction with sodium bicarbonate. USDA Circ. No. 939, Washington.

Sheldrick, W.F., Syers, J.K. and Lingard, J. (2011). A conceptual model for conducting nutrient audits at the national, regional and global scales. Nutr. Cycl. Agroecosystem, 62: 61-72.

Stanford, S. and English, L. (1949).Use of flame photometer in rapid soil tests for $\mathrm{K}$ and $\mathrm{Ca}$. Agronomy Journal, 41: 446-7.

Subbiah, B.V. and Asija ,G.L. (1956). A rapid procedure for the determination of available nitrogen in soils. Curr.Scie., 25: 259-260.

Tyler, G., Olsson T. (2001). Concentrations of 60 elements in the soil solution as related to the soil acidity. Europ. J. Soil Scie., 52: 151-165.

Wang, J., Raman, H., Zhang, G., Mendham, N. and Zou, M. (2006). Aluminum tolerance in barely (Horidium vulgarize L.): Physiological mechanisms, genetics and screening methods. Journal of Zhejing University of Sciences, 7: 769-787.

Walkey, A., and Black, I. A. (1947).Rapid titration method for organic carbon of soils. Soil Science, 37:29-32. 